\title{
DIE SKRIFBESKOUING VAN DIE REFORMATORE
}

\author{
DR. L. F. SCHULZE
}

Die tema is met opset só geformuleer want om hier te praat van 'n (formele) „inspirasieleer" of „inspirasie-teorie” van die reformatore sou 'n anachronisme wees.

Dát die Skrif deur God ingegee of geinspireer is (die Vulgaat vertaal die Theopneustos van 2 Tim. 3:16 met divinitus inspirata), het die Kerk van die begin af geglo. Omdat die Kerk voortdurend met die Skrif besig was, tref ons ook deur die eeue altyd bepaalde voorstellinge van die hoedanigheid van die inspirasie aan. Met name was dit die geval toe die Kerk teenoor die ekstatiese geesdrywery van die Montaniste opnuut moes gaan rekenskap aflê oor die aard van die Skrifinspirasie. Uit reaksie teen die Montanisme is die vroeëre gangbare entoesiastiese opvatting van die inspirasie prysgegee en is daar meer klem gelê op die „menslike faktor" $)$. $\mathrm{H}$. Cremer tipeer hierdie verandering in opvatting as 'n inruiling van die entoesiastiese vir 'n meer "meganiese" kyk op die inspirasie, waar die klem op die geestesoutoriteit van die Skrif as wonderbare boek gelê is ${ }^{2}$ ).

1. H. Bavinck, Geref. Dogmatiek, 4e dr. I, 374.

2. RE, 3e druk, IX, 184 vv. Otto Weber tipeer in sy Grundlagen der Dogmatik, I, 254 die meganiese inspirasie as. „Ausschaltung wenn nicht ihres Bewustseins, so doch jedenfalls ihrer Selbsttätigkeit und also im Grunde ihrer Zeugenhaftigkeit." Dit val sterk te betwyfel of die term ,meganies" en sy omskrywing 'n gelukkige keuse is. Dit word veral by Augustinus duidelik. Lg. word as eksponent van die meganiese inspirasie gesien vanweë sy bekende beskouing van die Skrif as „diktaat van die Heilige Gees" en van die bybelskrywers as „sekretarisse van die Gees." Dat dit egter by Augustinus kom tot uitskakeling van die menslike aktiwiteit kan nie aangetoon word nie. Hy bring inteendeel die menslike aktiwiteit in die volk gesigsveld. Vgl. die konklusie van A. D. R. Polman, Het Woord Gods bij Augustinus, 45: ,Elke gedachte aan een mechanische inspiratie is hier volstrekt uitgesloten. De Bijbelschrijvers zijn geen klerken, geen willoze organen van de Geest. maar werken en schrijven met volle verantwoordelijkheid." Vgl. ook die opmerking van Dieter Schellong in Calvins Auslegung der synoptischen Evangelien, 106: „Die Charakterisierung dieser Lehre als der einer ,mechanischen' Inspiration ist eine Vergröberung." 
In hierdie lyn het Augustinus verder gedink toe hy teenoor die aanvalle van die Manicheërs en Porphyrius homself van die Skrifinspirasie moes rekenskap gee $^{3}$ ). Hy wys sy opponente op die selfgetuienis van die Skrif, die kerk se belydenis van die inspirasie en gaan dan breedvoerig in op die goddelike en menslike komponente van die Skrif. Hy bring dit egter nie tot 'n uitgewerkte, teoretiese beskouing oor die inspirasie nie $\left.{ }^{4}\right)$. Trouens kan ons dit ook verstaan as ons bedink dat die kanon in hierdie einste eeue in die sentrum van die belangstelling gelê het terwyl die inspirasie, wat geen direkte ,strydpunt" was nie, aan die periferie van die kerklike aandag geleë was.

In die laat-Middeleeue is daar kragtig teruggegryp op die oudkerklike inspirasie-opvatting. Teenoor die willekeurige uitbreiding van die leer is beide in konsiliêre en opposisiekringe (Wicliff) weer gepraat van die bybelskrywers as "hand" en as "sekretarisse van die Gees". By Occam en Biel bereik die laatMiddeleeuse skrifprinsipe sy duidelikste vergestalting. Hier ontstaan, volgens die tipering van Kropatscheck, die „boekreligie”'). Die inspirasie dien hier om die bloot formele gesag van die Skrif te stut.

Watter erfenis Luther en die ander reformatore ook al aan Occam en Biel te danke het, één ding is duidelik: dat daar tussen hulle en die laat-Skolastiek $\delta \delta k$ 'n ingrypende verskil bestaan. Wat die Skrifbeskouing betref, formuleer Weber die verskil soos volg: „Die Reformatoren haben das ,sola scriptura von ganz anderen Gesichtspunkten her gewonnen als die Theologen des ausgehenden Mittelalters, nämlich nicht von der formalen auctoritas, sondern vom Inhalt her."'). Hoeveel van die tradisionele inspirasiebeskouing ook oorgeneem is (tot in die terminologie toe!), neem dit die feit nie weg dat hulle veel konkreter as die Skolastiek met die Skrif omgegaan het. Die inspirasie is nie 'n gegewe om die formele gesag van die Skrif te „bewys" of te ondersteun nie, maar dit kom ter sprake in verband met die inhoud en die karakter van die Skrif, veral wat betref sy betrou-

3. Polman. aw., 40. Die Manicheërs se teenwerpinge teen die Skrif het Augustinus genoop om De consensu Evangelistarum te skrywe. As hierdie noodsaak om die bybel teen lasteringe te verdedig nie bestaan het nie, sou Augustinus hom waarskynlik nie so breedvoerig oor die aard van die inspirasie uitgelaat het nie.

3. Polman, aw., 49, met verwysing na H. J. Vogels: St. Augustins Schrift „De consensu Evangelistarum”, 79.

5. Weber, aw., 255: F. Kropatschek, Das Schriftprinzip der lutherische Kirche, I, 444.

6. Aw., 355. 
baarheid, sy pedagogiese inslag en sy "nut" vir onsi). 'n Formele inspirasie-teorie word egter nie deur die reformatore gegee nie. 'n Mens soek tevergeefs in die Institusie 'n hoofstuk of selfs 'n paragraaf oor „Die inspirasie van die Bybel"'a). Uitsprake oor die inspirasie lê as min of meer terloopse opmerkinge verspreid oor die werke van die reformatore. Dit is weer eens verstaanbaar as ons daaraan dink dat dit nie die inspirasie was nie, maar die regverdiging deur die geloof wat in die brandpunt van hulle belangstelling gestaan het.

Dat die inspirasie presies op hierdie of daardie wyse plaasgevind het en ook só moes plaasvind, resp. dat God nie anders gewerk het of kon gewerk het nie - dit alles sou 'n inspirasieleer word wat vrug was van 'n meer rasioneel-analitiese benadering om die Skrif as formele gesagsinstansie te beskerm teen die aanslae van die rasionalisme van die $17 \mathrm{e}$ en $18 \mathrm{e}$ eeue en teen die historisme van die Romantiek.

II

Hierdie toedrag van sake moet ons op 'n dubbele manier versigtig stem: ten eerste, wat ons terminologie betref, naamlik om versigtig te wees met uitdrukkinge soos ,inspirasie-leer" en "Inspirasie-teorie" omdat ons daarmee 'n skewe historiese beeld van die Reformasie skep; ten tweede, om nie in die gedagtes van die reformatore oor die inspirasie ons eie beskouinge en die eietydse probleemstellinge in te lees nie - baie van ons probleemstellinge was vreemd aan hulle tyd, en wie meen om al die antwoorde op vandag se probleme by hulle te vind, doen niks anders as om die geskiedenis subjektief in te kleur nie.

Dit beteken egter nie dat die Reformasie niks vir ons te sê het nie. Ons het inderdaad hier met 'n rigtinggewende impuls

i. Schellong, aw., 126: Im Umgang mit der historia evangelica wie auch mit der alttestamentlichen Geschichte sieht es so anders aus, weil Calvin die Geschichte direkt auf ihren Nutzen hin befragt und den Menschen in ihr direkt mit dem Willen Gottes konfrontiert sieht." Hieruit mag ons egter nie (met die moderne problematiek van die geskiedenis op die oog) konkludeer dat die feitelike verloop van die geskiedenis vir Calvyn betekenisloos was nie. Die historiese betroubaarheid van die bybelse mededelinge was in die tyd van die Reformasie sonder probleme en is algemeen aanvaar. Calvyn betrek die geskiedenis op sy nuttigheid vir ons omdat die historia nie apart van die misericordia tot ons kom nie en ook nie sodanig deur ons begrvp moet word nie. Calvyn gaan dus nie die weg van Melancthon nie. Lg. onderskei die geloof sorgvuldig in notitia en fiducia en betrek die eerste aspek op die historia de Christo en die fiducia op die misericordia Dei - iets wat ons goed ken uit vraag 21 van die Heidelbergse Kategismus! Ook Bucer het hom uitgespreek oor die nut van die Skrif. Vgl. P. Stenhenc. The role of the Holy Spirit in the Theology of Martin Bucer, III: „It is certainly not enough to stop with the historical sense, for the Bible was written for our instruction ... The purpose of the Bible is practical - that we may know God and Jesus Christ whom he has sent."

ia. Schellong. aw.. 86: ,... denn schon der Inspirationsbegriff ist nicht Calvinisch, sondern eine Interpretation." 
te doen wat vir ons wat in die reformatoriese tradisie staan, in die huidige probleme nog die rigting kan aanwys waarin ons moet trag om die probleme op te los.

Met dié gedagte voor oë wil ons trag om die bogenoemde kort tipering van die Skrifbeskouing van die Reformasie in nadere besonderhede uit te werk. Weens die rykdom aan materiaal beperk ons ons tot Calvyn as verteenwoordiger van die reformatoriese beweging terwyl ons net sporadies na die ander belangrike reformatore sal verwys.

Wat Calvyn betref, begin ons met 'n paar algemene stellings na aanleiding van konkrete uitsprake van Calvyn. Vervolgens probeer ons om Calvyn uit sy eie werk te verstaan. Met ander woorde die betekenis van Calvyn se konkrete uitsprake word in die lig van ander uitsprake geinterpreteer om so deur te dring tot die bedoeling van hierdie hervormer. Ten slotte word die interpretasie gekontroleer met 'n besondere verwysing na sy Evangelie-harmonie.

Die laasgenoemde werk van Calvyn bied 'n goeie geleentheid om sy posisie en beskouing nader te bepaal, want dit kan vergelyk word met heelwat ander "harmonieë" wat destyds die lig gesien het. Ons sal ons beperk tot een van die mees uitgesproke en histories belangrike evangelie-harmonieë van daardie tyd, naamlik dié van Osiander ${ }^{9}$ ).

\section{III}

1. Calvyn stel dit duidelik dat die Heilige Gees die Outeur van die Woord van God, van die ,leer" en van die Skrif is ${ }^{9}$ ). Oor die vraag hoe Calvyn hom die outeurskap voorstel en wat hy presies daaronder verstaan, loop die meninge van die biograwe en navorsers wyd uiteen. Calvyn moes as vader staan vir elke denkbare inspirasie-teorie wat in die loop van die eeue ná die Reformasie onstaan het. $\mathrm{Hy}$ is getipeer as die „bron van die klassiek-protestantse inspirasieteorie” (Seeberg) en óok as „Vader van die wetenskaplike bybelkritiek" (J. A. Cramer), hy was verteenwoordiger van die grafiese (verbale) inspirasie (O. Ritschl), wat op ,die wyse van die emanasie voorgestel” moet word

*. Augustinus se werk bly hier buite beskouing. Dat sy invloed op dic reformatore ook in hierdie verband 'n groot rol gespeel het staan vas. Sy Evangelieharmonie in die aangehaalde werke van Polman en Vogels. Vgl. ook 'n oorsigtelike bespreking by Schellong, aw., 47 vv.

$\because$. Komm. Hand. 20:33: sic enim sua constat verbo Dei auctoritas, quum agnoscimus eius spiritum esse autorem. Meesal word God as auctor verbi of doctrinae aangedui. Christus is ook auctor verbi. Vgl. die sitate en verwysings by $w$. Krusche, Das Wirken des Heiligen Geistes nach Calvin. 161. Vgl. Inst. I. 9, 2: il (die Heilige Gees) veut estre recognu de nous en son image, laquelle il a imprimée aux Escritures. Il est l'autheur d'icelles. 
(Noesgen) én hy was iemand by wie daar van 'n inspirasie by die te boekstelling van die Skrif geen sprake kan wees nie $(\mathrm{H}$. Heppe, W. Niesel, Doumergue)! ${ }^{10}$ ).

Geen wonder nie, want by Calvyn is geen "sisteem" oor die inspirasie te vind nie. Trouens, in die trefwoord-register van die uitgawes van die Institusie van sowel Benoit as dié van Beveridge ontbreek die woord „inspirasie” eenvoudig. Sonder om hier by voorbaat vir een van die standpunte kant te kies, moet ons eers verder in Calvyn se eie werk soek om vas te stel wat hy presies met hierdie uitspraak van die Outeurskap bedoel.

2. Calvyn gee self van hierdie outeurskap van die Heilige Gees op talryke plekke 'n nadere omskrywing. Aan die hand van die pragtige en indringende opsomming van Krusche ${ }^{11}$ ), kan ons dit kortliks soos volg weergee.

2.1. Die Bybelse skrywers (getuies) word met 'n hele reeks uitdrukkinge omskrywe: hulle is organe en instrumente van die Gees; mense deur wie se mond Hy gespreek het; hulle is gewisse en outentieke (geloofwaardige) skrywers of notarisse van die Heilige Gees; hulle is skrywers of griffiers onder die mond van $\left.\operatorname{God}^{12}\right)$.

1". Krusche, aw., 161. „Man kann hier werklich alles finden”, met verwysing na 'n opsomming van al die standpunte by D. J.' de Groot, Calvijns opvatting over de inspiratie der Heilige Schrift. p. 12-32. Verwysings na die werke van bogenoemde outeurs by Krusche, p. 161-162.

11. Krusche, aw., p. 162 v. Daar is ook talryke verwysings na die werke van Calvyn waar hierdie uitdrukking gevind kan word.

12. Vgl. vir die uitdrukking "organe" of ,instrumente" van die Heilige Gees: Calvini Opera, deel 23, kolom $6(=$ C.0.23,6); C.0. 24, 205; 24. 274. Verder: C.O. 23, 85: spiritus per os Petri testatur; C.0. 23, 38: spiritus per os Mose refert; C.O. 32, 642: le sainct Esprit, qui a parlé par la bouche de David; Inst. IV, 8, 9; certi et authentici amanuenses; dieselfde woord in die Franse vertaling: notaires authentiques. Ten slotte twee belangrike sinne uit 'n preek oor Deut. 31:22-30 (C.0. 28, 647): notons, que ce mot „d'Escriture" emporte que Moyse n'a point esté autheur de la Loy ne du Cantique: mais qu'il a esté seulement escrivain ou greffier sous la bouche de Dieu. Toit ainsi qu'un secretaire escrira ce que luy sera ordonné: ainsi notamment il est ici declaire que Moyse a escrit ce qu'il avoit receu de Dieu, et non pas ce qu'il a forgé en son cerveau. Die laaste sinsnede is nie maar by wyse van hipotetiese kontras aan die betoog aangelas nie, maar dit kom juis neer op hierdie laaste woorde: die skrywer of sekretaris skryf neer alleen dit wat hy ontvang het, dit wat hom beveel is en nie dit wat hyself bedink en uit sy brein voortspin nie.

Verskeie van dié uitdrukkinge (bv. „organe”) stam reeds uit die tyd van die kerkvaders, terwyl Augustinus ook snreek van die bevel om te skrywe (Bavinck, aw., I. 374; Polman, aw., 41). Die uitdrukking certi et authentici amenuenses het Calvyn moontlik van Bucer. wat dit reeds in 1536 gebruik het, oorgeneem (Krusche, aw. 162). Meeste van die beelde is dus nie oorspronklik nie, maar dit is sterk beelde moontlik té sterk na die smaak van Heppe en Niesel. Hulle gaan al hierdie uitdrukkinge verby, moontlik omdat dit nie inpas in hulle interpretasie van Calvyn nie! 
2.2. Die werk van die Outeur ${ }^{1.5}$ ) ten opsigte van die "skrywers" word ook deur verskillende uitdrukkinge omskrywe: die Heilige Gees het die bybelse getuies die woord in die mond gelê, die woorde in hulle mond laat invloei; die Gees het aan die bybel„skrywers" die woorde gedikteer. Laasgenoemde uitdrukking kom baie by Calvyn voor en is seker die mees tiperende aanduiding van die werk van die Heilige Gees ten opsigte van die bybelskrywers ${ }^{14}$ ).

2.3. Die trefkrag van hierdie dictare is wyd: dit het nie net betrekking op die inhoud van die Skrif nie, maar ook op die vorm. Bepaalde redewendinge, uitdrukkingsvorme en styleienaardighede word uitdruklik aan die Heilige Gees toegeskryf. Calvyn kan selfs praat van die "styl en taal van die Heilige Gees"15). Ons noem nog twee bepaalde voorbeelde in dié verband: die Heilige het gewil dat Ps. 119 volgens die letters van die alfabet opgebou moet word, sodat dit, net soos die Onse Vader, die geestelike besit van almal sal word; en $\mathrm{Hy}$ het gewil dat die kruisroep „Eli, Eli, lama sabachtani?” in die ,,siriese” taal meegedeel sal word om dit des te beter in ons gedagtes in te prent ${ }^{16}$ ).

Met hierdie gegewens in die hand is dit baie maklik om die konklusie te trek: „Dus is Calvyn die vader van die ortodokse (verbale) inspirasieleer! Dit is tog glashelder!" Hierdie konklusie is ook inderdaad al vele male geponeer.

13. Dit is tog betekenisvol dat Calvyn die Heilige Gees on die bybelskrywers nie as auctor principalis of primarius en auctores secundarii tipeer nie. Daar is net eén Outeur van die Skrif en dit is God. Só het die kerkvaders dit ook reeds gesê. Vgl. Bavinck, aw., I, 374 oor die opvatting van die kerkvaders: „... de schrijvers waren de handen des Heiligen Geestes, zij waren de auctores niet, maar alleen scriptores, scribae; auctor der Heilige Schrift is God alleen" (Vgl. Irenaeus, Adv. Haer, II. 28: die Skrif het één outeur en één doel!) Die term auctor secundarius is klaarblyklik 'n latere konstruksie, Vgl, ook Krusche, aw., 165-166.

14. Calvyn praat van: in os suggerere, of van: ori inserere ori indere. Vgl. sy kommentare op Jes. 40:1 (C.0.37, 4). Deut. 18:18 (C.0. 24, 274), Num. 23:4 (C.O. 25, 279). Dictare kom dikwels voor. Ons noem net 'n paar gevalle: Inst. IV. 8, 8: idipsum tamen non facerent (d.i. die apostels) nisi ex Domino. hoc est. praeeunte et verba quoddammodo dictante Christi Spiritu: (C.0. 38, 314): quod dictabat spiritus sanctus, obedienter promulget (dit is Jeremia) tanquam fidele eius organum; C.O. 24, 34 (komm. Ex. 2:10): quod nobis utile erat dictavit spiritus, et quasi in os illius suggesit. Suggerere en dictare staan dikwels by mekaar soos in lg. sitaat. Verdere verwysings na die gebruik van dictare by Krusche. aw.. 163.

1.. In 'n preek oor I Kor. 10:15-18 (C.O. 49, 666): Ainsi donc retenons le style et language du $\mathrm{S}$. Esprit. Vgl. ook Inst. I, 8, 2: mais par tels exemples (d.i. die elegante spreekwyse van die profete) le sainct Esprit a voulu monstrer qu'il n'estoit point despourveu d'eloquence, quand ailleurs il luy plaisoit d'user d'un stile grossier et rude. Sulke uitdrukkinge kom ook by Luther voor: „Der Hl. Geist spricht keinen Kurialstil" (sitaat by Krusche, aw., 164 aant. 209).

16. C.0. 32, 502 en komm. Matt. 27:46 (C.0. 45, 779). 
Hoef ons nog verder te gaan? Dit skyn oorbodig te wees, want die slag is gelewer. Calvyn het tog self hier nader verklaar hoe hy die Outeurskap van die Heilige Gees ten opsigte van die Skrif sien.

Die reformatore het al baie gely onder ons oorhaastige konklusies, waarin ons hulle terme interpreteer en hulle uitdrukkinge lees soos ons dit graag gelees wil hê. Want ons staan voor die eienaardige situasie dat die reformatore óok dinge gesê het wat eenvoudig nie inpas in die "sisteem" wat ons so haastig uit hulle uitsprake konkludeer nie. Daarom moet ons verder gaan en vra: wat het Calvyn met „skrywers", „organe”, ensovoorts bedoel? Wat het hy met dictare bedoel? Hoe en in watter verband gebruik hy dié uitdrukkinge en hoe "funksioneer" hulle in sy werk? Wat is die draagwydte van ,die taal en styl van die Heilige Gees"?

Calvyn moet dus self (weer eens!) hierdie tweede reeks uitsprake verklaar.

3.1. Die getuies van Christus (in hulle spreke en skrywe) word aangedui as organe en instrumente, as "skrywers" (escrivains) en griffiers. Nou is dit opvallend wat sekere (tradisionele en/of later geliefde) beelde, sover ek weet, by Calvyn ontbreek. Die Augustiniese beeld van die apostels as "hande" van Christus kom by Calvyn nie voor nie ${ }^{1 i}$ ). Ook die aanduiding calamus (riet, rietfluit of pen) ontbreek. Dit lyk na 'n klein verskil om van „skrywers" te praat en nie van „lewendige penne van die Heilige Gees" soos Calov byvoorbeeld later sou doen nie $\left.{ }^{18}\right)$. In wese maak dit 'n groot verskil of jy 'n sekretaris of maar net sy pen is! Calvyn „verdinglik" nie die bybelskrywers nie. Hy gebruik organiese of personale beelde om hulle aan te dui!

Dit op sigself is ' $n$ belangrike saak. Hierdie toedrag van sake word verder bevestig as ons let op die verband waarin Calvyn van die "skrywers" praat en die interpretasie wat hy self aan die begrip gee. Die eerste wat opval is dat die term „skrywer” (amanuensis, notaire, ens.) baie seldsaam by Calvyn voorkom ${ }^{10}$ ).

1i. Vgl. Polman, aw., 41 oor die verband waarin Augustinus clié beeld gebruik. ..Hand van God" is die naam wat aan die Heilige Gees self toegeken word. Inst. III, 1. 3: il (die Heilige Gees) nous est proposć . . comme la main de Dicu, par laquelle il exerce sa vertu (Act. 11 . $21)$.

1*. . S. scriptores fuerint tantum calamus. manus vel amanuenses spiritus S. (aanhaling by Krusche, aw., 166, aant. 220). Dis opvallend dat amanuensis hier deur die begrip calamus geïnterpreteer word!

19. Krusche. wat die werke van Calvyn sorgvuldig nagegaan het. vind dat daar. afgesien van die laaste twee verwysings in aant. 12. nog net twee plekke is waar Calvyn hom van die woord bedien. t.w. in 'n preek onr I.uk. 1:1-4 (C O. 46. 6) en die niteensetting van .Jer. 29:25 (C.O. 38, 606). Hy skryf: ... dieser Begriff ist für Calvin keineswegs kennzeichnend (aw., 164). 
Insiggewend is ook die alternatiewe term waarmee hy hierdie begrip verklaar, naamlik minister, bedienaar!"00). Die bedienaar is as 'n ware bedienaar 'n outentieke getuie en skrywer. Teenoor die auctor of auctor principalis ${ }^{21}$ ) staan as teëpool (en daaraan georiënteer) nie die auctor secundarius of die amanuensis nie, maar die minister. Dit is die bedienaars self wat spreek en skrywe, maar hulle weet van wie hulle hulle doctrina het ${ }^{22}$ ). Ons sien hier die bybelse getuienis met hul spreke en skrywe met hulle beperktheid, bepaaldheid en afhanklikheid. Hulle is net bedienaars en nie auctor nie. Tog word hulle nie daarmee gedegradeer tot dinge (,riete”, ,fluite”, ,penne”) nie. Inteendeel hulle is geroepe, ,,aangestelde' amptelike en gevolmagtigde bedienaars en ook as sodanig ,skrywers" ${ }^{\prime 3}$ ).

Teenoor die begrip minister staan dus dié van auctor. Teenoor die begrip „skrywer" staan dié van „privaat persoon"."4). Die "skrywers" was geen privaat persone nie, maar as't ware „publieke" amptelike gevolmagtigdes. Dit is dan ook opmerklik dat, oral waar Calvyn die verskillende begrippe vir "skrywer" gebruik, die aksent glad nie op die aktiwiteit van die "skryf" lê nie, maar wel op die feit dat hulle optrede amptelik was en nie privaat nie. Calvyn wil met die beeld van die "skrywer" die feit van hulle outentieke, betroubare getuienis uitdruk ${ }^{25}$ ).

:". Besonder belangrik is die recds genoemde preek oor Luk. 1 waar Calvyn die ,.skrywer" as minister interpreteer - presies in die ander koers as wat Calov dit doen! Hy skryf: ils sont ministres . . . de sa parole: c'est à dire qu'ils ont esté ordonnez de Dieu comme ses notaires autentiques. In Afrikaans. „Hulle is bedienaars . . . van sy woord; d.w.s. dat hulle deur God verordineer ( $=$ bestem, bevestig, aangestel) is as sy outentieke notarisse" Vgl. ook C.0. 46. 9: ils sont nommez "Ministres", c'est à dire, tesmoins autentiques. (..Hulle word .bedienaars' genoem. d.w.s. outentieke getuies"). Opmerklik dat die minister hier op die voorgrond staan terwyl die ..outentieke skrywers" of ..getuies" die ..bedienaar" nader omskryf. Ons moet Krusche dus toegee as hy opmerk. ..Der zentrale Begriff zur Charakterisierung der Offenbarungs - zeugen ist vielmehr ganz ohne Zweifel der des minister (aw. 164; bogenoemde sitate ook daar. aant. 211).

$\because$. C.O. 46. 164. . . les hommes mortels en sont ministres: mais il faut venir à l'auteur princípal . . . (Sitaat meer volledig bv Krusche, aw.; 165 , aant. 213 asook verdere verwysings na die kombinasic van „outeur”; en ,bedienaar").

$\because$. C.0."46. 163: Vgi. ook die slotopmerking in ant. 12.

$\because$. Die amanuenses in die Institusie word in die Franse vertaling ,notaires jurez, du sainct Esprit."

․ C.0. 53. 338 (preek oor I Tim. 4:1-2): . les saincts Prophetes... n'estoyent pas personnes privees; C.0. 46. 164 (preek oor Luk. 1:65-68): Zacharie n'a point parlé en homme privé, mais que le $\mathrm{S}$. Esprit l'a possedé ... (sitate by Krusche. aw., 166. aant. 222). Krusche sê tereg: ..Die Inspiration reiszt den zeugen aus seiner privaten und stellt ihn sozusagen in eine amtliche Sphäre (p. 166).

$2:$. Dat die gewig vir Calvyn inderdaad op die amntelike en die betroubaarheid van dit wat hulle getuig. lê. word duidelik as Calvyn in sv voorwoord tot die apokriewe boeke (C.0. 9. 827) die verskil tussen die kanonieke en die apokriewe hoeke vergelyk met 'n getrienis van 'n notaris. wat deur sv hande gegaan en deur hom verseël is, teenoor die geskrif van 'n privaat persoon (vgl. Krusche, aw., 166). 
3.2. Wat beteken die aanduiding van die inspirasie van die Gees as 'n ,dikteer?"

Ten eerste moet ons opmerk dat ons hier 'n histories belaste term het wat uit die tyd van die kerkvaders stam. Tweedens is dit opvallend dat Calvyn al die geliefde terme van Augustinus óok tesame met die dictare gebruik ${ }^{26}$ ). Nou weet ons dat Calvyn 'n uitnemende kenner en 'n getroue dissipel van Augustinus was. Hy kan byvoorbeeld heftig teenoor Pighius opmerk dat hy (Calvyn) oor die uitverkiesing nie 'n woord meer gesê het en wil sê as Augustinus nie. Dit is dus die moeite werd om insake hierdie terme ook te vra of Calvyn nie hier in die lyne van Augustinus beweeg nie.

Kortliks kan ons, wat die hantering van die terme betref, vasstel dat geen een van hierdie terme by Augustinus 'n dogmatiese fiksering het nie. Hy praat van die ,inspirasie" van die bybelse getuienis en skrywers, maar hy gebruik obk die term om verskillende werkinge van die Gees in die gelowiges te karakteriseer. Hy praat byvoorbeeld van die inspirasie van die geloof of van die goeie wil, of van die liefde of van 'n vrome onrus $^{2 i}$ ). Hy sal die uitleg van 'n moeilike skrifgedeelte aandurf vir sover die Gees hom dit sal inspireer ${ }^{28}$ ). Tog inderskei hy tussen die inspirasie van die bybelskrywers en dié van die gelowiges: daar is in die twee gevalle 'n essensiële onderskeid in die effek van die inspirasie. Dieselfde ruimheid tref ons in die begrip dictare aan. Die evangeliste het as lede „onder diktaat van die Hoof" geskrywe. Hieronymus moet die Skrif verklaar omdat die Gees hom dit nie alleen gee nie, maar dit ook dikteer ${ }^{20}$ ). Dictare beteken dus hier: „,beveel” ${ }^{30}$ ). Die woord kan ook beteken: gelas, aandring, iemand aansit om iets te doen. In watter sin die woord in De consensu Evangelistarum, I, 54 vertaal moet

26. Augustinus gebruik naas dictare dikwels inspirare, suggerere en gubernare, (Polman, aw., 42).

:- Polman, aw.. 43, met verwysing na De gratia Christi, 43; De gratia et lihero arbitrio 3, 9; Epist. 130, 2.

2*. Enarr. in Ps. 126, 1. Polman merk tereg op: ,.Daaruit blijkt onweerlegbaar, dat deze term bij Augustinus nog allerminst dogmatisch gefixeerd is", (p. 43).

29. Epist. 82, 1, 2: non tantum donante, verum etiam dictante spiritu, (sitaat by Polman, aw. 43).

31. So Polman. aw., 43-44. Vgl. ook ander vertalings van die sitaat uit aant. 29). Cunningham (Letters of Saint Augustine, 318): not only given you, but expressly charging you; Kranzfelder (Bibl. der Kirchenväter, VII. 314) Denn der Heilige Geist hat es dir nicht nur verliehen, sondern er befiehlt es dir. (Beide sitate by Polman, aw., 43). 
word, is onseker $\left.{ }^{31}\right)$. Die woord suggerere beteken waarskynlik „indagtig maak" of "herinner” terwyl gubernare ook vir die algemene leiding van God gebruik word. Hieruit is in elk geval duidelik dat geen inspirasieteorie op een of almal van hierdie terme gebou kan word nie.

By Calvyn kan ons daadwerklik dieselfde tendense vasstel. Die term inspirare kom nie baie voor nie. Calvyn gebruik dit in ieder geval ook in 'n algemene $\sin ^{32}$ ). Dié woord het dus geen domatiese gewig by Calvyn nie. Calvyn het 'n groter voorliefde vir dictare en gebruik dié term ook meer genuanseerd as Augustinus, maar ook by eersgenoemde het dit geen dogmatiese fiksering nie. Dit word duidelik as ons die gebruik van dictare by Calvyn kortliks oorsien.

3.2.1. Hy praat dikwels van quasi dictare (en ook van quasi suggerere) waarby hy duidelik 'n figuurlike spreekwyse te kenne $\left.\mathrm{gee}^{33}\right)$. As dié taalryke Calvyn met sy fyn onderskeidinge 'n quasi, tanquam of quodammodo neerskryf, mag ons nie argeloos daaroor heen lees asof dit per toeval daar staan nie!

3.2.2. Die woord word (net soos by Augustinus) gebruik om 'n bevel van die Heilige Gees uit te druk (bv. by die vrou met bloedvloeiing wat die soom van Jesus se kleed moet aanraak en by die kiesing van Matthias $\left.{ }^{34}\right)$. Dictare beteken hier: die mens

31. Polman, aw., 44.

:2. Of Calvyn ooit inspirare gebruik i.v.m. die Skrifleer, kon ek nie vasstel nie. In sy kommentare op II Tim. en II Petr. kom die woord nie voor nie. Nóg Krusche nóg Schellong behandel die woord of gee enige verwysings na Calvyn se werke waar die woord voorkom. 'I'eenoor Pighius kan Calvyn egter opmerk dat die menslike oorleg en die beskerming van homself deur God in die mens geinspireer is. Vgl. Rec. des Opuscules, 319: . . . l'industrie de consulter, et se garder a este inspirec de Dieu aux hommes. In II Petr. 1:20 en II Tim. 3:16 kom uitdrukkinge voor wat reeds hierbo aangedui is en "tipies" van Calvyn is. So merk hy by II Petr. 1:20 onder meer op: "Summa est: hoc esse rectae intelligentiae initium, dum fidem, quae Deo debetur, tribuimus sanctis eius prophetis. Sanctos Dei homines appellat, qui iniunctum sibi munus fideliter exsequentos divinam in suo ministerio personam sustinuerint. Impulsos fuisse dicit. non quod mente alienati fuerint ... sed quia nihil a se ipsi sausi fuerint, tantum obedienter sequuti sint spiritum ducem, qui in ipsorum ore, tanquam in suo sacraria regnebat.

Ook II Tim. 3:16 beklemtoon die inspirasie as 'n nie uit jouself spreek nie: . . . quod scimus Deum nobis loquutum esse, certoque persuasi sumus. non ex suo sensu loquutos esse Prophetas, sed ut erant Spiritus Sancti organa, tantum protulisse quae creditus mandata fuerant. Quisquis erga vult in Scripturis proficere, hoc secum in primis constituat, Legem et Prophetas non esse doctrinam hominum arbitrio proditam, sed a spiritu sancto dictatam . . .

33. Inst. IX, 8, 8: . . . et verba quodammodo dictante Christi Spiritu; C.O. 38, 432: . . et quasi illis verba dictat; C.O. 24, 34 (by Ex. 2:10): quod nobis utile erat dictavit Spiritus. et quasi in os illius suggesit. (sitate by Krusche, aw., 167 aant. 226). In lg. sitaat word die dictare dus omskryf as quasi suggerere!

34. Vgl. sy kommentaar op Mat. 9:20 (C.O. 45. 257): hoc illi a spiritu fuisse dictatum; Ook in die kommentaar op Hand. 1:23v. word dieselfde sinsnede gebruik. 
se doen en late is nie meer aan sy eie goeddunke onderwerp nie, maar hy moet God onvoorwaardelik gehoorsaam.

3.2.3. Die woord word voorts betrek op die belydenis voor die wêreld en op die besluite van die konsilies. As die dissipels, voor die wêreld gedaag word, hoef hulle hul nie te bekommer oor wat hulle sal sê nie, want die Gees sal hulle dikteer wat hulle moet sê. (Matt. 10:20). Hier word inderdaad van 'n woordelikse diktaat (verba dictare) gespreek, maar dit word nie op die Skrif of hulle te boekstelling van die Skrif betrek nie, maar op hulle sprake en belydenis voor die maghebbers van die wêreld. By Hand. 15:28 merk Calvyn op dat as die apostelkonvent effens onafhanklik van die Gees (seorsum a spiritu) begin het, sou die grondreël (axioma) genegeer word, naamlik dat deur die konsilies niks besluit sou word nie behalwe dit wat deur die Gees gedikteer is ${ }^{35}$ ). Tensy ons die vergesogte gedagte wil deurvoer dat die "besondere inspirasie" ook op die belydenis en belydenisvorming en op die kerklike besluite en dogmavorming van toepassing is - dan het ons die reformatoriese grond nie meer onder die voete nie! - sal ons wel versigtig moet wees om nie so gemaklik uit die dictare ' $n$ verbale inspirasieleer af te lei nie. Die sin van „dikteer” is hier veeleer: om niks uit jouself te sê of te wil sê nie, maar om jou God toe te vertrou, wat sorg dat sy waarheid sal seëvier. Die dictare eis dus dat die eie-ek van die getuies en skrywers tot swye gebring word. Dit beteken nie dat die mens nou 'n "stok en 'n blok" word vir wie die woorde een-een ingegee of voorgesê moet word nie. Dit beteken wel dat die mens deur God geleer moet word, want die natuurlike mens ken die dinge van God nie en kan dit ook nie verkondig nie. Hierdie „negatiewe" funksie van dictare (niks uit jouself sê nie, dit wil sê niks vleesliks sê nie) is van fundamentele belang by Calvyn $^{36}$ ). Daarvan getuig die reeks uitdrukkinge wat as antitese by dictare staan, byvoorbeeld ex scipso, ex corde, suas imaginationes proferre, ensovoorts.

By die dictare kom dus nóg die eie aandrif, nóg die eie (vleeslike) gedagte ter sprake. Inteendeel, hier lê die Gees beslag op 'n mens sodat sy denke en spreke as getuie onder die absolute

35. C.O. 48, 363. nihil a conciliis determa, praeter spiritus dictata.

34. Krusche. a.w., 168: Diese negation ist der Herzpunkt von Calvins Inspirations - „Lehre”. By die 27 verwysings wat hy maak na plekke waar dictare teenoor die ex seinso staan, kan ons nog die een uit die Institusie (IV, 8,8 ) byvoeg. Nadat hy van die Gees se diktaat aan die dissinels gepraat het (Vgl. aant. 33) vervolg hy: Car le Seigneur Iesus a limité tout leur ambassade en ceste sorte, leur commandant d'aller et enseigner, non point ce qu'ils auroyent forgé à la volée d'eux-mesmes, mais seulement tout ce qu'il leur avoit enioint. 
beheer van God kom, sodat die mens (nie in ekstatiese sin nie) "buite homself" is." ) die onrein lippe word rein, die onverstandige hart word reseptief gemaak vir die goddelike openbaringshandele en -spreke wat betroubaar outentiek deurgegee moet word ${ }^{35}$ ).

Dictare beteken dus positief: alleen God se woord spreek en ook die volle Woord spreek; outentiek getuig sonder vleeslike leuenagtigheid en onverstandigheid - en daarvoor sorg God self deur die dictare!

3.3. Dat die uitdrukking: „taal en styl van die Gees" nie só letterlik verstaan moet word dat dit hier om 'n woordelikse "ingee" van Gods Woord gaan nie, word duidelik uit die verrassende "tekskritiese” opmerkings van Calvyn. Ons volstaan deur daarop te wys dat hy sommige tekste of uitdrukkinge as randglosse beskou wat in die teks ingesluip het, en dat hy die "foute" nie net op rekening van die afskrywers sit soos Bavinck ${ }^{39}$ ) meen nie, maar ook op rekening van die bybelskrywers!40). Sulke "foute" is vir 'n verbale inspirasie fataal en ondenkbaar.

4. Dit is duidelik dat die gegewens in verband met "skrywers" en in verband met dictare vanself korreleer. Dit gaan om beveel en gehoorsaam, voorgaan en navolg ${ }^{11}$ ).

Met hierdie gegewens in gedagte kan ons vervolgens let op die Evangelie-harmonie van Calvyn in vergelyking met dié van Osiander.

:i. Calvyn praat van mens of sensus of lingua spiritu gubernari Cresp. regi, dirigi. (Verwysings by Krusche. aw.. 169 aani. 231). Vgl. ook: intelligit ita se fuisse gubernatum Dei spiritu, ut dissimilis esset a se ipso (C.O. 40, 86, oor Eseg. 3:14).

39. C.O. 38, 231 (Jer. 15:18): quia spiritus sanctus et mentem eius, et sensus omnes, et linguam sic direxit, ut nihil esset illic humanum. Voorts moet ons opmerk dat Calvyn (anders as Calov later doen en soos Bavinck wel later doen) onderskei tussen openbaring en Skrif. God openbaar en verlig voordat Hy inspireer (C.O. 25, 279 - waar die inspirasie van die profete in teenstelling tot die woordelikse voorsê van Bileam se profesie ter sprake kom!) Daarom gaan dit by die inspirasie om die outentieke weergawe, deurgawe, getuienis van die openbaring. Calvyn praat daarvan dat dit wat van God gegee is van hand tot hand verder gegee word (a Deo traditum acceptum de manu in manum tradere, C.0. 42,$203 ; 37,9 ; 39,11 ; 44,94$, e.a.) Dit is geen woordelikse ingee nie (die bvbelskrvwers is nie gramofoonplate nie). - Tog lei die Gees hulle ook by die keuse van woorde sodat daar nie vleeslike en filosofiese formuleringe insluin nie - quasi dictare! Dit gaan dus nie net om die inhoud wat geïnspireer is nie.

39. Bavinck, aw., I, 384.

41. Oorvloedige materiaal in die verband by Krusche, aw., 173 vv.

41. Vgl. ook Schellong se konklusie: „Dictare" enthält wie .,praeire”. . . das Moment der Verordnung zu einem Amt, des Befehls und damit der Autorisierung ... (aw., p. 86). 
In sy voorwoord sê Osiander dat hy die harmonisering van die evangelies onderneem het in die oortuiging dat die evangeliste sodanig geinspireer is dat hulle geen woord of letter in hulle boeke sou invoeg nie, tensy dit deur die waarheid van die geskiedenis vereis is en deur die Gees geapprobeer is. Die Heilige Gees het die evangeliste nie in die steek gelaat sodat hulle aan die gebrekkigheid van hulle gedagtes uitgelewer was om onsekerhede vir die waarheid op te dis nie. Alhoewel self onbekwaam, is hulle deur die Gees bekwaam gemaak.

Wat die bekwaammaking inhou en watter konsekwensies daaruit voortvloei, toon Osiander met behulp van 'n viertal tekste aan:

4.1. Matt. 10:20: Hierby merk hy op dat as die Gees reeds by die mondelinge, onvoorbereide spreke die gedagtes en woorde lei, hoeveel te meer sal $\mathrm{Hy}$ dit by die te boekstelling doen, wat wel sorgvuldiger voorberei word en baie meer mense moet bereik?

4.2. Matt. 15:17-19: Hier argumenteer hy van die mindere na die meerdere: As daar reeds van die mosaise wet geen jota of tittel kan wegval nie, hoeveel te meer geld dit dan nie van die evangelie van Christus; want die Evangelie is „ministerium spiritus ac vitae"; dit is met ander woorde deur die Gees ingegee „et in aeterno dei consilio ab aeterno praedestinatum"12). Die tiperende van Osiander se beskouing kom in hierdie merkwaardige konklusie aan die lig, en lê daarin dat die evangelie van Christus met die geskrewe evangelie in sy viervoudige gestalte ge-identifiseer word.

4.3. In aansluiting by Joh. 12:49 en ander Johannestekste word hierdie gedagte nog verder gevoer: die evangeliste vertel wat hulle van Christus gesien het, en dit het Christus, soos $\mathrm{Hy}$ self uitdruklik sê, van die Vader ontvang. Daarom moet ons glo dat alles wat die evangeliste te boek gestel het, van ewigheid af vasgelê is. Anders maak ons Christus tot leuenaar.

4.4. Luk. 10:16(a): Met hierdie woord van Christus sluit Osiander af: „Wie julle hoor, hoor My"(!)

Vir die evangelie-harmonie beteken dit dat die evangeliste, alhoewel hulle verskeie persone is en op verskeie plekke en tye skryf, tog éen en dieselfde sê. Die evangelie-harmonie moet dan hierdie „eenheid" van die evangeliste aan die lig gebring en dparmee die inspirasie van die Skrif aantoon. In 'n sekere sin "bewys" die evangelie-harmonie die inspirasie.

42. Latynse aanhalings breedvoerig by Schellong, as., 81 . 
Osiander was baie ingenome met sy werk ${ }^{43}$ ). Dat hy inderdaad hier 'n pynlike stuk monnike-werk gelewer het, is onteenseglik. Hy het die vier evangelies woordeliks in een laat smelt sodat 'n enkele, nuwe, samehangende verhaal tot stand gekom het. Elke afsonderlike woord van die vier evangelies het behoue gebly en is in die nuwe teks opgeneem. Slegs by parallelle waar net verskillende sinonieme of werkwoordsvorme voorkom en geen verdere variasies nie, is 'n keuse vir die beste lesing gemaak terwyl die variante (net sinonieme en tempus!) in die kantlyn aangeteken is. Bowendien het Osiander by elke woord deur middel van letters as simbole aangedui (a) waarvandaan die woord geneem is; (b) of dit uit 'n enkele evangelie kom en uit welke; (c) of dit parallel by verskeie evangelies voorkom en by welke! 'n Onvermydelike konsekwensie van sy metode was dat hy in die lompheid van die sinne alleen verstaanbaarheid en vloei kon kry deur ryke interpunksie en die reëlmatige toevoeging van 'n kai wat nie in die oorspronklike teks staan nie $\left.!^{44}\right)$. Hierdie arbeid word pragtig deur Schellong tipeer: „Das Unter nehmen lässt sich an ehesten sofern es nicht ironisch verstanden wird - mit einem Puzzlenpiel vergleichen" ${ }^{45}$ ). Nodeloos om te sê dat hierdie mees konsekwente evangelie-harmonie, hierdie opus magnum van Osiander nutteloos was.

Wat ons wel interesseer, is die onderliggende Skrifbeskouing wat die hele projek dra. Of Osiander werklik so oorspronklik in sy beskouinge was, hoef nie hier beantwoord te word nie. Feit bly staan dat ons hier by die eerste geslag Reformatore reeds so 'n merkwaardige uiteensetting van die verbale inspirasie aantref. Nie A. Calov of Joh. Gerard of Flacius is die vader van die verbale inspirasie nie; ook nie Calvyn, soos O. Ritschl beweer nie - dit was Osiander. Met Osiander as aanknopingspunt kan ons 'n beter oorsig oor die posisie van Calvyn verkry. Dit geld des te meer omdat Calvyn die werk van Osiander geken het en hom ook doelbewus met Osiander (kontroversieel) besig gehou het. Die vraag is: hoe het Calvyn op die verbale inspirasieleer van Osiander gereageer?

43. Die naam „Evangelie-harmonie” het deur Osiander se werk 'n vaste term geword. Dit het in 1537 by Froberius in Basel verskyn. Vgl. Schellong. aw., 46: Wer es (die werk) nicht kennt, kann eigentlich nicht restlos von der Autoritä́t der Evangelien überzeugt sein", met verwysing na Osiander se voorwoord.

41. Breedvoerige bespreking van die werk by Schellong, aw., $43 \mathrm{vv.} \mathrm{Interes-}$ santheidshalwe 'n enkele voorbeeld, nl. die roeping van Mattheüs. Die teks is 'n samestelling van Matt. 9:9, Mark. 2:14 en Luk. 5:27(b) -28 en lees, tesame met die randvariante in hakies, soos volg: Kai parágoon o Iésous ekeithen, eiden (etheásato) anthroopon teloonen. onomati Leuei, ton tou Alfaaiou. Kathémenon epi to teloonion, Matthaion legomenon, Kai legei (eipen) autooi. Akolouthei moi. Kai Katalipoon apanta. anastas ékolouthésen autooi.

45. aw., 43 . 


\section{IV}

Die perikoop Matt. 5:17-19 speel, soos ons reeds gesien het, 'n deurslaggewende rol by Osiander, as sleutel beide vir die synoptiese probleem en vir sy skrifbeskouing in die geheel. Ook Flacius het hierdie perikoop op dieselfde wyse en met dieselfde motivering (naamlik van die Skrifinspirasie) gebruik" ${ }^{16}$ ).

Calvyn betrek hierdie gedeelte op die onderrig van die wet en nie op die doen van die wet nie, aangesien die mens van nature daartoe onbekwaam is en selfs die gelowige die wet nie kan volbring nie. Die goeie leermeester sal aandring op die gehoorsaming van die wet en sal daarteen waak dat die gesag van die wet ondermyn word. Hy sal ook met sy lewenswandel 'n voorbeeld wees. Hier kom die doen van die wet dan wel in die gesigsveld, dog nie as vervulling (impletio legis) nie maar as voorbeeld (examplum). „Wet” is vir Calvyn hier die lewensvoorskrif, die tien gebooie. Opmerklik dat Calvyn hom hier nie uitlaat oor die skriftelike fiksering en die geïnspireerdheid van die woorde nie. Dit gaan vir Calvyn hier om die gesag van die wet as wet van God. Ons mag nie ligtelik oor die wet heenstap en die gesag daarvan misken nie. Christus sê dat die waarheid van die wet onwankelbaar en vas is soos niks anders ter wêreld nie. Die swaartepunt lê dus op die gesag van die wet, die waarheid van die wet, wat Christus in sy doctrina vir ons bekend maak. Vandaar word die lyn verder deurgetrek na die egte en suiwere leer van die kerk. Dit is dus opmerklik dat Calvyn hierdie andersinds so „fundamentele” perikoop nie gebruik as bewys van die inspirasie nie $\left.{ }^{4 i}\right)$.

Die gebruik van die beelde wat Osiander en Calvyn aanwend om die ,harmonie" van die evangelies aan te toon is ook insiggewend. As Osiander oor die harmonie van die evangelies praat, gebruik hy 'n beeld uit die musiek om dit te verduidelik - en natuurlik ook hoe hy deur sy werk hierdie harmonie eers hoorbaar maak! Calvyn daarenteen gebruik net die begrip „harmonie" en nie Osiander se beeld uit die musiek nie. Ter verduideliking gebruik hy twee beelde uit totaal ander lewensfere om die hàrmonie van die evangelies te verduidelik ${ }^{18}$ ). Dit kon nie anders as met opset geskied het nie. Osiander se beeld was te veel op

11i. Schellong, aw. 83 met literatuurverwysinge.

4:. Ibid. p. 84. Die bespreking van hierdie teks in die Institusie (II. 17, 14) gaan in dieselfde rigting. Op ' $n$ verdere plek in die Institusie (II. 8,59) kom dié gedeelte weer ter sprake in die polemiek teen die R.K. onderskeiding van vergeeflike sonde en doodsonde: die geringste oortreding van die wet is miskenning van Gods soewereiniteit.

1e. Dié beelde kom net in die voorwoord van sy Evangelie-harmonie voor en nie in die kommentaar self nie. 
sy eie werk toegespits en het ook niks meer uitgedruk as dat ure evangelies byeen hoort en onderling ooreenstem nie. Die eerste beeld, wat Calvyn van Augustinus oorneem, is dié van die Quadriga: die evangelie is die triomfwa waarop die Here sy intrek in hierdie wêreld neem ${ }^{49}$ ). Daarmee word die evangelies totaal anders gekarakteriseer as wat Osiander met sy musikale en letterlike strakheid doen. Hier kom oog vir die verkondigingskarakter van die evangelies. Buonop word 'n ander kloof wat Calvyn van Osiander skei hier sigbaar, naamlik dat hier onderskei word tussen Christus en die evangelies. Christus benut immers die evangelies om in eie Persoon sy intog in hierdie wêreld te hou. Daardeur word die diens van die getuies (evangeliste) nie waardeloos nie, want dit is juis deur hulle wat $\mathrm{Hy}$ tot die mense kom en vir hierdie taak het God hulle ook geroep en aangestel. Christus is die oorwinnaar en die Koning wat juis deur dié dinge wat die evangeliste van Hom berig die mense onder sy septer bring en die Kerk so grondves en regeer.

Hierdie Augustiniese beeld is fundamenteel. Al die afsonderlike trekke van die beeld tref ons steeds weer aan in die geskrifte van Calvyn. Telkens hoor ons dat die evangelies deur God verorden is, en hiermee hang saam onderskeid tussen die verkondiging en die Verkondigde ${ }^{50}$ ). Maar dis ook die evangeliste wat verordineer is, geroep is, aangestel is om getuies en bedienaars van die Woord te wees. Daarom maak Calvyn hom nie moeg om vas te stel of, volgens die tradisie, die skrywer van Markus ' $n$ leerling en sekretaris van Petrus was nie $e^{\text {h1 }}$ ) en hy toon aan dat Paulus nie Hebreërs kon geskryf het nie; maar verder bemoei hy hom nie met die outeurskap nie. Dat die bybelskrywers amptelik opgetree het as geroepenes van God, is vir hom voldoende. Die beklemtoning van die outoriteit van die Skrif en van die Skrifleer as ampsleer moet ons lei tot sekerheid. Ons geloof is nie afhanklik van twyfelagtige mensewoorde nie en hoef

4". C.0. 15, 712. Vgl. De Consensu Eu. I, 7, 10; Schellong aw., 85.

… Schellong, aw. 86: „Das Wesen der Calvin'schen Ausprägung der Inspirationslehre ligt in der Verordnung der Evangelien durch Gott, zu der die Unterscheidung zwischen der biblischen Verkündiging und dem in ihr verkündigten Herrn gehört."

$\therefore$. Insake die outeurskap van Markus sê Calvyn: ,Qua de re non est anxie nobis laborandum, quia nostra parvi refert. modo teneamus legitimum ac divinitus ordinatum esse testem, qui nihil nisi praecunte dictanteque Spiritu sancto prodiderit". (cR. 453) Teenoor O. Ritschl wat in die dictare ' $n$ aanduiding van die verbale inspirasie sien, het Krusche afdoende aangetoon dat die woord hier met beveel vertaal moet word en wvs op die ampielike en outoritatiewe optrede van die skrywer. Vgl. Krusche: Das wirken des des IIl. Geistes nach Calvin, 167 vv.; Schellong, aw., 86. 
nie onseker en wankelend te wees nie. Korellaat met die amptelike karakter van die getuies en hulle getuienis is die woord persuasio, certitudo, securitas wat Calvyn so vele male in verband met die geloof gebruik. Schellong merk tereg op: „Amt und Gewissheit sind die zwei Angeln, in denen die Schriftlehre Calvins hängt". (p. 88). Hierdie amptelike outoriteit of inspirasie geld - dit het reeds duidelik geword maar ons moet dit beklemtoon - die mondelinge getuienis sowel as die te boekstelling van die Skrif en die prediking in die kerk. Tog het die bybelskrywers hier in hul outoriteit 'n besondere rang. Dit lê daarin dat Calvyn nog iets van hulle sê, naamlik dat God hulle die opdrag gegee het om nie net mondeling te getuig nie, maar ook skriftelik sy waarheid vir alle tye vas te lê. Hulle het die skrifte ook versamel (Lukas) en bewaar. Daarom is daar in die onderskeie evangelies ook 'n wonderlike ooreenstemming. Beteken dictare nou nie tog méér as beveel nie? Gaan Calvyn nie van die ampsroeping tog oor om hom rekenskap van die inspirasiegebeure en die tot standkoming van die Skrif te gee nie? Inderdaad, as God beveel, sorg Hy dat dit gedoen word. God roep ook nog só tot die prediking van hierdie woord waaroor Hy sy hand hou. ,, Inspiration' meint also den ganzen Akt des Werdens der Bibel, von den Vorstufen der mündlichen Verkündigung an bis zur Durchsetzung der Schrift in der Kirche. Und wenn die Schrift in der Geschichte der Kirche in ihrer Autorität verschüttet wird, ist es wieder Gott selber, der ihr zu neuer Geltung verhilft, der abermals und weiterhin, inspiriert." "' ${ }_{52}$ ). Krusche se konklusie gaan in dieselfde koers as hy skryf: „Calvin . . zeigt . . . das Inspiration für ihn nicht ein Prädikat sein kann das der Bibel zukommt, sondern; dass damit ein Handeln Gottes des Heiligen Geistes gemeint ist das den biblischen zeugen in ihrem Sprechen und Schreiben widerfährt. Der naheliegende Schluss, weil die biblischen Zeugen inspiriert waren, ist auch die Bibel inspiriert, würde übersehen, das dann beide Male mit Inspiration etwas sehr vershiedenes bezeichnet wäre; im einen Falle ein pneumatischer Akt, im anderen die supranaturale Qualität eines Buches (,Inspiriertheit')"533).

Die verkondigde Here hou die getuies en hulle diens in sy hand en skep daardeur steeds weer gehoorsame onderdane. Daarom noem Calvyn die Skrifwoorde dikwels speculum, specimen, imago van die Woord van God, en dikwels sê hy dat God „quodommodo" in die Skrif spreek. Hy laat egter ook dikwels laasgenoemde woord weg en identifiseer die spreke van God met die Skrif. Hy kan dit doen omdat dit vir hom gaan om die duide-

\footnotetext{
52. Schellong, aw., 91. Hy verwys na Calvyn se brief aan Karel V: God het Luther verwek; sy ministerium het die gemeentes gegrondves en gevorm.

53. Krusche, aw., 128. Sitaat by Schellong, aw., 91.
} 
likheid, betroubaarheid van die promissio Dei en om die persuasio en securitas van die geloof in hierdie belofte. Dit moet tog duidelik wees dat die konfrontasie met die Skrif op die ontmoeting met die lewende God, die Deus loquens afstuur. Ons kan teen die aanslae en verdraaiing van die Satan alleen stand hou as die duidelikheid en betroubaarheid van die Skrif ook in ons duidelik en betroubaar deur die Gees, wat Here van die Skrif is, bevestig word. Bowendien is die konfrontasie met God se spreke ook: opname onder die kinders van God en gemeenskap met sy Seun. In die Christusgemeenskap loop alle lyne saam wat tot dusver getrek is. Hy, die Here kom op die Quadriga om sy Kerk te stig en in sy gemeenskap te bewaar.

Die tweede beeld is ook aan Augustinus ontleen. Hier word die evangelies met vier basuine vergelyk wat na al vier die windstreke geblaas word om die Kerk uit die ganse wêreld te versamel ${ }^{54}$ ). Ook hierdie beeld bevat 'n kerugmatiese element maar die beeld het hom veral geleen tot spekulasie oor die viertal evangelies. Daar was dan ook inderdaad 'n oorweldigende tradisie van spekulasies oor die viertal en oor die funksie van elke evangelie in hierdie viertal. Nou is dit opmerklik dat Calvyn nêrens enige belangstelling vir hierdie spekulasies toon nie en geen behoefte het om die betekenis van die viertal aan te dui nie. Ook dit is betekenisvol om sy houding teenoor die Skrif te verstaan.

\section{$\mathrm{V}$}

Dit is duidelik dat Calvyn in 'n ander lug asem haal as Osiander. Daar is wel ooreenkomste: albei skryf 'n evangelieharmonie en die opset is vir albei dieselfde: dit gaan om die agting van die goddelike gesag van die Skrif en dat hierdie gesag nie twyfelagtig word nie, want dan wankel die geloof. Ook Calvyn kan hom, nes Osiander (en hierin het Augustinus hulle voorgegaan) nie voorstel dat daar gedeeltes van die bybel is en ook gedeeltes van die evangelies is, wat mekaar weerspreek nie. Hierby hou die ooreenkomste egter op.

Die verskille is groter. Formeel is daar al verskille: waar Osiander al vier die evangelies kommentariëer, doen Calvyn dit net met die eerste drie. Hy sien die synoptiese evangelies as vlees en die Johannes evangelie, wat apart uitgelê word as die „,siel". Johannes is die primêre wat lig op die synoptiese evangelies werp. Waar Osiander die vier evangelies in een enkele nuwe geheel vleg, gaan Calvyn in navolging van Augustinus en

54. CR 15, 712; De consensu Ev. I, 2, 3. 
Bucer uit van Matt. en voeg die ander evangelies eintlik in hierdie "geraamte" in. Tog word die tekste van die onderskeie evangelies nie ineen gevleg nie, maar langs mekaar afgedruk.

Waar Osiander die klem van die „soveel te meer" op die te boekstelling laat val, lê Calvyn daarop klem dat die getuienis (ook skriftelik) alleen 'n getroue weergawe van die openbaring moet wees, (by die „briewe" val openbaringe en weergawe saam) Christus en die evangelie, openbaring en Skrif word hier nie geidentifiseer nie. Dit sou prakties uitloop op vergoddeliking van die Skrif ${ }^{5}$ ).

Calvyn se beskouing is só wyd dat dit in die verbale inspirasie-teorie nie inpas nie en in geen ander teorie nie. Ons kan „elemente" van omtrent alle teorieë hier vind - tot die aktualistiese van Barth! Maar ons moet oppas vir vereniging. Die wonder van die inspirasie is só groot, dat ons dit nie in 'n rasionele teorie kan vasgryp nie. Ons kan ons teorieë sonder vrees láát, want God sorg self dat sy Woord altyd weer gehoor en begryp word - ook te midde van die historiese vrae en vraagtekens van vandag.

.3. Bavinck, aw., I, 385 oor die proefskrif van Nietzsche of die Heilige Skrif self God is! 